\title{
Türkiye'de Yerli Dizilerin Kadına Yönelik Şiddetle Mücadele Algısı Üzerine Etkileri
}

\author{
DOI: $10.26466 /$ opus. 975120
}

\author{
Can Ozan Tuncer ${ }^{*}$ - Serpil Seda Şimşek ${ }^{* *}$ - Naci Akdemir*** \\ * Dr. Öğr. Üyesi, Van Yüzüncü Yıl Üniversitesi, Van/Türkiye \\ E-Posta: canozantuncer@gmail.com \\ ORCID: 0000-0001-9471-4917 \\ ** Öğr.Gör., Jandarma ve Sahil Güvenlik Akademisi, Ankara/Türkiye \\ E- Posta: ssedasimsek@gmail.com \\ ORCID: $\underline{0000-0001-8016-5566}$ \\ *** Dr. Öğr. Üyesi, Jandarma ve Sahil Güvenlik Akademisi, Ankara/Türkiye \\ E- Posta: naci.akdemir@jsga.edu.tr \\ ORCID: 0000-0002-4288-6482
}

Öz

Kadına yönelik şiddetle mücadele son yıllarda Türkiye'de en önde gelen kamu politikalarnndan biri olmuştur. Kadina yönelik şiddet araştırmalarnnı sayılarında kayda değer bir artış meydana gelmesine rağmen, yerli dizilerin kadına yönelik şiddet algısı üzerindeki etkileri henüz kapsamlı olarak araştırlmamıştır. Ampirik çalışmamızm amaçlarından birincisi Türkiye'deki kadına yönelik şiddetle mücadele algısın ölçmek, ikincisi ise yerli dizilerin kadına yönelik şiddetle mücadele algısı üzerindeki etkilerini incelemektir. Bu amaçlara yönelik olarak, İçisleri Bakanlı̆̆ı İç Güvenlik Stratejileri Dairesi Başkanlığı'nca yürütülen bir çalışma kapsamında toplanan anket verisi nicel analize (Mann-Whitney, Kruskal Wallis ve Stral Lojistik Regresyon analizleri) tabi tutulmuştur. Analiz sonuçlarn, kadina yönelik şiddetle mücadele algisında cinsiyet ve yaş farklliklarmı işaret etmektedir. Sonuçlara göre, kadınlar, gençler (18-24 yaş) ve yaşl (55 yaş ve üstü) bireyler. kadina yönelik şiddetle mücadeleyi diğer demografik gruplara göre daha yetersiz bulmaktadır. Diğer yandan, dizi izleme sıklğ̆, şiddet içerikli, polisiye, hapishane ve kadına yönelik şiddet temah dizileri sıklkla izleme kadına yönelik şiddetle mücadele algısınn yordayıcları olarak belirmiştir. Araştırmamız yerli dizilerin kadına yönelik şiddetle mücadele algisı üzerinde olumlu etkileri olduğunu ve yerli dizilerin kadına yönelik şiddet hakknda durumsal farkndalı yaratmak konusunda faydalı olduğunu göstermektedir. Bu bağlamda, politika yapıclar, kadına yönelik şiddetle mücadele stratejilerini geliştirirken, kadına yönelik şiddetin türleri ve şiddetin kadın üzerindeki olumsuz psikososyal etkileri konusunda toplumun bilinçlendirilmesinde, erkeklerin farkındalk düzeylerinin yükseltilmesinde yerli dizilerin etkilerinden yararlanmayı düşünebilirler.

Anahtar Kelimeler: Kadına yönelik şiddetle mücadele, kadına yönelik şiddet, yerli dizi. 


\title{
The Impact of TV Series on the Perception of Combating Violence Against Women in Turkey
}

*

\begin{abstract}
Combating violence against women has been one of the leading public policies in Turkey in recent years. Though there is a significant increase in research on violence against women, the impact of TV series on the perception of violence against women is understudied. The first aim of our empirical study was to understand how combating violence against women is perceived in Turkey. The second was to examine the effects of TV series on the perception of tackling violence against women. To these ends, the survey data collected by the Department of Internal Security Strategies of the Ministry of Interior as a part of the research were subjected to quantitative analysis (Mann-Whitney, Kruskal Wallis and Ordered Logistic Regression analyses). Analysis results indicate gender and age differences in the perception of combating violence against women. The results suggest that women, young people (18-24 years old) and the elderly (55 years old and above) find the combating violence against women inadequate compared to the other demographic groups. The frequency of watching TV series and TV series themed with violence, crime, prison and violence against women emerged as the predictors of the perception of combating violence against women. Our research illustrated that TV series impacted the perception of violence against women positively and that domestic TV series may help raise situational awareness about violence against women. With this regard, policymakers may consider utilizing the effects of TV series on raising awareness in society about the types of violence against women and the adverse psycho-social impacts of violence on women while developing strategies to combat violence against women.
\end{abstract}

Key Words: Combating violence againts women, violence againts women, TV series. 


\section{Giriş}

Şiddet, döngüsü gereği sadece doğrudan şiddet uygulanan insanları değil, onların çocuklarını ve daha sonraki kuşakları da etkileyen ve öğrenilerek aktarılan bir olgudur. Şiddet, hemen her türü ile insanların sorun çözme, empati geliştirme ve hassasiyet gösterme paradigmalarını bozmaktadır (Güleç, Topaloğlu, Ünsal ve Altıntaş, 2012). Şiddet uygulamayı bir problem çözme yolu olarak görmenin suç davranışı ile ilişkili olduğu bilinmektedir. Araştırmalar, şiddet mağduru çocukların, ilerleyen yaşlarında şiddet uygulama potansiyeli yüksek bireyler olabileceklerine işaret etmektedir (Özgentürk, Karğın ve Baltacı, 2012). Özellikle çocukluk çağı travmaları, çocukluk, ergenlik ve yetişkinlik dönemlerinde şiddete maruz kalma, şiddet suçu işleme ve başkalarını şiddet karşısında mağdur bırakma gibi yansıtmalarla, bir toplumsal sorun olarak karşımıza çıkmaktadır (Manchikanti Gómez, 2011). Bu bağlamda, kadına yönelik şiddetle mücadelede elde edilecek başarı, toplum hayatının sağlıklı bireylerle sürdürülmesinde büyük önem taşımaktadır. Ayrıca, şiddet, bir insan hakları ihlalidir ve çok çeşitli disiplinlerde üzerine çalışmalar yapılmaktadır.

Bir toplumda, kadına yönelik şiddete bakış açısının ve kadına yönelik şiddetin türlerinin ve şekillerinin en çarpıcı şekilde yansıdığı mecralardan birisi medyadır. Bu bağlamda medyanın, kadına yönelik şiddet olgusuna yaklaşımı ve bunu nasıl aktardığı önemlidir. Medya, kimi zaman olayları değiştirerek sunmakta ve çerçevelemektedir. Medya, bunu yaparken aynı zamanda değerler ve o değerlere uyan bir dünya kurgulamakta yahut inşa etmektedir (Tozlu ve Solak, 2008, s.51). Toplumsal cinsiyet rolleri ve medya arasında yaşanan kısır döngüde, bir toplumdaki kültüre göre toplumsal cinsiyet rollerinin dağılımı medyaya yansır, medya ise kendisine yansıyan bu toplumsal cinsiyet rollerini tekrar topluma yansitarak, sürecin devamin ve üretimini sağlar. Bundan dolayı da medyanın o toplumda yaşayan kişilerin rollerinin ve kişiliklerinin şekillenmesinde son derece etkin bir araç olduğu söylenebilir (Şener, Çavuşoğlu ve Irklı , 2016, s.166).

Gerek yazılı gerekse görsel medya, reyting ya da tiraj kaygısı sebebiyle ilgi çekebilecek, sansasyonel haberlere, reklamlara, dizilere, filmlere yönelirken, şiddetin ilgi çekici işlevselliğini kullanmaktadır. Medyada şiddet olgusunun çoğunlukla çocuk ve kadın odaklı ele alındığını, şiddetin döngüsünün de erkekten kadına ve kadından çocuğa doğru olduğunu söylemek 
yanlış olmaz (Yazıcı ve Şahbaz, 2020, s.135). Haberlerde, dizilerde, filmlerde, reklamlarda kadına yönelik şiddeti sıradanlaştıran ya da meşrulaştıran ifadelerin kullanılması, kadına yönelik şiddetle mücadeleyi zayıflatan bir sorun olarak karşımıza çıkmaktadır. Hatta Dursun (2010, s.21), şiddetin ortaya çıkma sebeplerinden birisi olarak eşitsiz güç ilişkilerinin yanı sıra medya kuruluşlarını görmektedir.

Türkiye'de her üç kadından birisi şiddete maruz kalmaktadır (Altınay ve Arat, s.110). Kadının Statüsü Genel Müdürlügü̈'nün (KSGM) (2009), verilerine göre, Türkiye'de evli kadınların yüzde $44^{\prime}$ ü, duygusal istismar eylemlerinden birisiyle karşılaştığını, kadınların yüzde 37'si eşlerinin kendilerine hakaret içeren sözler söylediğine, evli kadınların beşte biri aşağ1lanıp küçük düşürüldügünü, yüzde $19^{\prime} u$ da tehdide maruz kaldığını belirtmiştir. 2019 yılında kadına yönelik 186 bin 556 şiddet olayı meydana gelirken. 206 bin 43 kadın mağdur olmuştur (İçişleri Bakanlığı İç Güvenlik Stratejileri Dairesi Başkanlığı, 2020, s.33.). Bu rakamlar, kadına yönelik şiddetin Türkiye'de önemli bir problem olmaya devam ettiğini göstermektedir.

Türkiye'de son yıllarda kadına yönelik şiddete ilişkin çalışmalarda önemli bir artıs meydana gelmiştir. Kadına yönelik şiddetin nedenleri (KSGM, 2009; T.C. Aile ve Sosyal Politikalar Bakanlığı Kadının Statüsü Genel Müdürlüğü, Hacettepe Üniversitesi Nüfus Etütleri Enstitüsü, 2014; T. C. Aile ve Sosyal Politikalar Bakanlığı, Hacettepe Üniversitesi Nüfus Etütleri Enstitüsü, 2015), kadına yönelik şiddetin olumsuz etkileri (Doğrucan ve Yıldırım, 2020; Altıparmak, 2019), faillerin özellikleri (Akkuş ve Yıldırım, 2018; Erden ve Akdur, 2018) başlıca araştırma konuları arasında sıralanabilir. Bu konuların yanı sıra, medyanın kadına yönelik şiddet sunumu (Erdem, 2020; Nisan ve Işık, 2020) da araştırılan önemli konulardan biridir. Ancak yerli televizyon dizilerinin kadına yönelik şiddet algısı üzerine etkilerini inceleyen kapsamlı bir çalışma bulunmamaktadır.

Türkiye'de kadına yönelik şiddetle mücadele etmek maksadıyla Kadın Acil Destek (KADES) uygulaması yürürlüğe girmiş, ayrıca Şiddet Önleme ve İzleme Merkezleri (ŞÖNIM) faaliyete geçirilirmiştir. Kadına yönelik şiddetle mücadele kapsamında hayata geçen bu olumlu uygulamaların toplumda nasıl algılandığı tam olarak ortaya konulmamıştır. Mevcut çalışma, öncelikle büyük bir örneklem üzerinden toplumdaki kadına yönelik şiddetle mücadele algısını ölçmeyi amaçlamıştır. Araştırmanın bir başka amacı da yerli dizilerin kadına yönelik şiddetle mücadele algısı üzerindeki 
etkilerini incelemektir. Bu kapsamda, İçişleri Bakanlığı İç Güvenlik Stratejileri Dairesi Başkanlığınca yürütülen bir çalışma kapsamında toplanan veriler, kurumdan alınan izinle betimsel, iki değişkenli (Kruskal-Wallis H ve Mann-Whitney U) ve çok değişkenli (Sıralı Lojistik Regresyon) istatistiksel analizlere tabi tutularak aşağıdaki iki araştırma sorusuna yanıt bulunmaya çalışılmıştır:

-Türkiye'de kadına yönelik şiddetle mücadele nasıl algılanmaktadır?

-Yerli dizileri sıklıkla izleyen bireyler ile izlemeyen bireylerin kadına yönelik şiddetle mücadele algıları arasında istatistiksel olarak anlamlı bir farklilık var midır?

\section{Alanyazın Taraması}

\section{Kadına Yönelik Şiddetin Tanımı}

Dünya Sağlık Örgütü (DSÖ), kadına yönelik şiddeti bir halk sağlığı sorunu olarak tanımlarken, kadına yönelik şiddetin kadın haklarının ihlali olduğu ve toplumsal cinsiyet eşitsizliğine dayandığı görüşünü benimsemektedir. Yıldırım'a (1998, s.25) göre, şiddet, fiziksel ve/veya ruhsal zarar ya da acı veren saldırgan davranış biçimidir. Şiddet insanlar arasında huzur bozan, yıkıcı bir davranıştır. Michaud (1991, s.7), şiddetin, bir kimsenin gördüğü güç veya baskı sebebiyle isteği dışında bir şey yapması, duyguların kaba bir şekilde anlatılmasına dönük doğal eğilim olduğunu belirtmiştir. Sancar (2013, s.216) eril şiddeti, "yaş, sınıf, cinsiyet ve etnisiteye dayalı hiyerarşilerle yapılandırılmış ve en güçlünün kazanacağı biçimde örgütlenmiş bir davranışlar bütünü olarak" olarak tanımlamıştır. Sancar'a (2013, s.216) göre, eril şiddet, "düzen, disiplin, terbiye, namus, şeref gibi ahlaki değerleri merkezine alan ve en temel tekniği her türden şiddet olan toplumsal ve siyasal ilişkiler biçimidir".

Ailenin Korunması ve Kadına Karşı Şiddetin Önlenmesine dair kanunda ise şiddet, "Kişinin; fiziksel, cinsel, psikolojik veya ekonomik açıdan zarar görmesiyle veya acı çekmesiyle sonuçlanan veya sonuçlanması muhtemel hareketleri, buna yönelik tehdit ve baskıyı ya da özgürlüğün keyfî engellenmesini de içeren, toplumsal, kamusal veya özel alanda meydana gelen fiziksel, cinsel, psikolojik, sözlü veya ekonomik her türlü tutum ve davranışı" olarak tanımlanmaktadır (Resmi Gazete, 20 Mart 2012). 
Bir toplumda, kadın ve erkeğin davranışlarını tayin eden kültürel değerler, kadın ve erkek cinsiyet rolleri olarak algılanmaktadır. Kadın ve erkek rollerini üstlenme, evde başlayarak, aile ilişkilerinde, okulda, işyerinde, alışverişte sürdürülmektedir (Özcan, 2012, s.12). Bu roller toplumların kültürlerine göre biçimlenmekte ve toplumdan topluma farklılık göstermektedir (Ökten, 2009, s. 303). Türk toplumunda kadın ve erkeğe yüklenen özellikler şöyle açılanabilir (Dökmen, 2009, s.109):

Kadınlar için beklenen özellikler: Etkileyici, fedakâr, duygusal, çekici, düzenli, görgülü, iyi huylu, zarif, yumuşak, terbiyeli, kibar, sabırlı, pratik, sevecen, sevimli, saygıll, itaatkâr, sadık, tatlı dilli, üretken.

Erkekler için beklenen özellikler: Cesur, kavgacı, mücadeleci, atılgan, sert, çevik, mert, bağımsız, soğukkanlı, dayanıklı, güçlü, hırslı, hakkını savunabilen, sporsever, girişimci, hızlı, kendine güvenen, otoriter.

Kadınları darp eden, şiddet uygulayan, taciz ve tecavüzde bulunan eril kişiler, tam da bu rollere uyarlayarak verdikleri ifadelerde, genellikle töre, namus ya da kadınların bedensel durumlarından etkilendikleri için böyle bir davranışa başvurduklarını aktarmaktadır (Yazıcı ve Şahbaz, 2020, s.135). Toplumsal cinsiyet eşitsizliğinin üzerine inşa edilen şiddet kavramı, güçlü birisinin kendisinden daha güçsüz kişiye yönelik saldırgan davranışı olarak ifade edilmektedir. Şiddetin oluşumunda pek çok unsurun etken olduğu söylenebilir. Statü ve eğitim farkı, kültürel farklılıklar, aile yapısı, yaşam tarzları gibi birçok neden şiddetin mazereti olarak sayılabilir. KSGM'ce yapılan bir araştırmaya göre, kadına yönelik şiddetin nedenleri arasında şunlar yer almaktadır (KSGM, 2009, s.83-84) :

- Maddi sikınt,

- Eşinin ailesi ile ilgili yaşadığı sorunlar,

- Erkeğin iş sorunları,

- Erkeğin sinirli ve kıskanç olması,

- Erkeğin ayrilmak istemesi.

- Evde yeterli gidanın olmamasi,

- Kadının ihanetinden şüphe duyulması.

Şiddetin oluşumuna kaynaklık eden bu tip gerekçelerin yanı sıra, kadının ev işlerini aksatması, erkeğin sözünü dinlememesi, cinsel ilişkiyi reddetmesi, erkeğin aldatıyor olması, erkeğin kötü alışkanlıkları, erkeğin dışa- 
rıda vakit geçirmek istemesi gibi gerekçeler de şiddetin sebepleri arasında gösterilmektedir. Şiddet gören kadının tepki göstermesi, bağırması, şiddeti kabullenmemesi, ayrılmak veya boşanmak istemesinin ise şiddetin dozajını artırarak şiddeti körüklediği ileri sürülmektedir (KSGM, 2009, s.83 - 84).

\section{Kadına Yönelik Şiddetin Boyutları}

Dünyanın farklı ülkelerinde, her 3 kadından 1'i yaşamları boyunca çoğunlukla fiziksel ve / veya cinsel şiddetin konusu olmaktadır ( World Health Organization, 2021). Dünya Sağlik Örgütü (WHO) verilerine göre, sosyoekonomik durumu düşük bölgelerde 35-44 yaşlar arasındaki kadınların şiddet görme oranları yüksektir. Fiziksel ya da cinsel şiddet gören kadınların yüzde 42'si şiddet sonucunda yaralanmıştır (World Health Organization, 2013).

Türkiye'de 2016-2018 yılları arasında 206'sı jandarma, 726's1 polis bölgesinde olmak üzere toplam 932 kadın cinayeti işlenmiştir (Taştan ve Küçüker, 2019, s.9). 6284 sayılı kanun kapsamındaki kadın cinayetlerinin ise 2014-2020 yılları arasında, 307'den 267'ye gerileyerek yüzde 13 oranında azaldığ1 açıklanmıştır (İçişleri Bakanlığı, 15 Nisan 2021). Içişleri Bakanlığı verilerine göre, 336 kadın cinayeti 2019 yılında işlenirken, 2020 yılı içerisinde kadın cinayetlerinde yüzde 21'lik bir azalış meydana gelmiş ve işlenen cinayet sayısı 267'ye gerilemiştir (İçişleri Bakanlığı, 9 Nisan 2021).

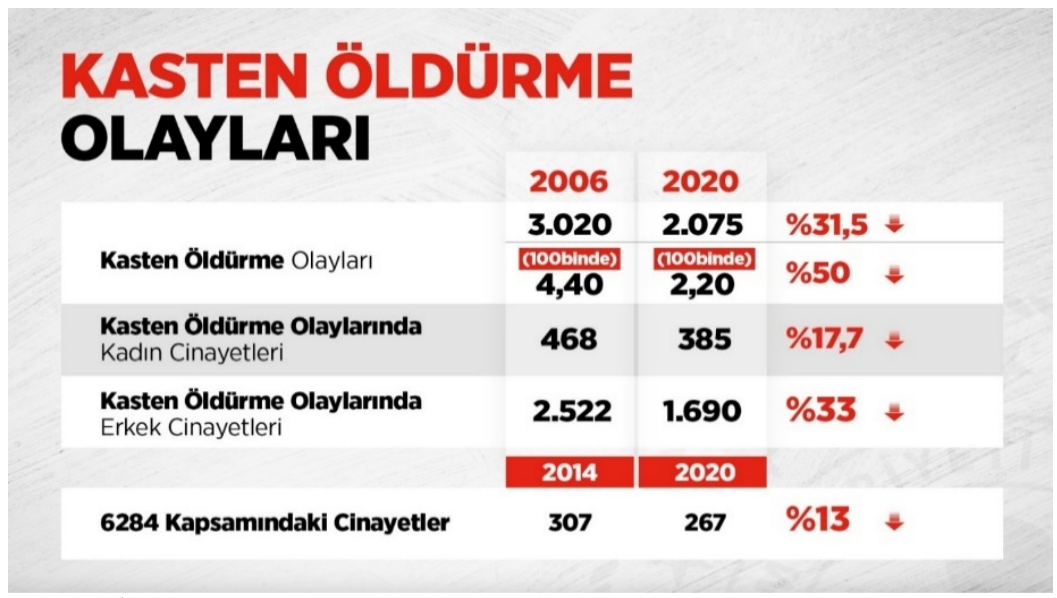

Kaynak: İçişleri Bakanlı̆̆ı, 15 Nisan 2021 
Emniyet Genel Müdürlüğü ve Jandarma Genel Komutanlığı'nın verilerine göre, Türkiye'de "Aile İçi ve Kadına Karşı Şiddet Olay Verileri" şöyledir (İçişleri Bakanlığı İç Güvenlik Stratejileri Dairesi Başkanlığı, 2020, s.33.)

Tablo 1. Türkiye'de Aile İçi ve Kadına Karşı Şiddet Olay Verileri

\begin{tabular}{lll}
\hline Yıl1 & Olay Sayısı & Mağdur Sayıs \\
\hline $\mathbf{2 0 1 6}$ & 162.110 & 177.434 \\
2017 & 180.307 & 193.363 \\
2018 & 219.801 & 253.336 \\
2019 & 186.556 & 206.043 \\
$2020(6$ Ay) & 117.192 & 126.880 \\
\hline
\end{tabular}

Bu veriler kapsamında, 2016 -2020 tarihleri arasında Türkiye'de aile içi ve kadına yönelik şiddet konusunda mağdur sayısında genel bir artışın yaşandığı tespiti yapılabilir. 2019 yılında aile içi şiddet mağduru kadın sayısında \%19 civarında bir azalma meydana gelirken, bu yıl içerisinde yaşamını yitiren kadın sayısı, 2018 yılına göre yüzde 23 oranında artış göstermiştir. 2021 yılının ilk 3 ayında 6284 sayılı Kanun kapsamına giren 55 bin 231 olay meydana gelmiştir. Önceki senenin aynı dönemi ile karşılaştırıldığında, olay sayısında \%8'lik bir düşüş görülmektedir (İçişleri Bakanlığı, 9 Nisan 2021).

Ayrıca, 2019 yılında, kadın cinayeti nedeniyle hayatını kaybeden kadınların sadece \%6'sı tedbir kararı aldırmıştır (İçişleri Bakanlığı İç Güvenlik Stratejileri Dairesi Başkanlığı, 2020, s.33). Koruyucu tedbir kararı, 2020 yılında ise 2019 yılına göre artmıştır. 2020 yılında, , şiddet uygulayanlara yönelik önleyici tedbir kararında ise yüzde 64 oranında artış meydana gelirken, şiddet mağdurlarına yönelik koruyucu tedbir kararında yüzde 39 azalma görülmüştür (TRT Haber, 2 Ocak 2021). 2021 yılının ilk 3 ayında ise şiddet uygulayan 53 bin 447 kişiye yönelik 159 bin 9 önleyici tedbir, 18 bin 37 şiddet mağduruna 17 bin 121 koruyucu tedbir kararı verilmiştir (İçişleri Bakanlığı, 9 Nisan 2021).

İstanbul, Ankara, İzmir gibi nüfus bakımından yoğun olan büyük şehirlerin kadın cinayetlerinde ön planda olduğu görülmektedir. Nüfus yoğunluğunun ve göçün olumsuz sosyolojik etkilerinin kadın cinayetlerinin anılan şehirlerde yoğunlaşmasında etkili faktörler olduğunu söylemek mümkündür (İçişleri Bakanlığı İç Güvenlik Stratejileri Dairesi Başkanlı̆̆ı, 2020, s.35). 


\section{Faillerin Demografik Özellikleri}

Dünyada ve Türkiye'de kadına yönelik şiddetin biçimleri çeşitlilik göstermekle birlikte, araştırmalar şiddetin daha çok kadınların evli veya boşanmış olduğu eşleri, sevgilisi, çocukları ya da akrabalarından, yani kendilerine yakın erkeklerden geldiğini göstermektedir. Birleşmiş Milletler Uyuşturucu ve Suç Ofisi'nin (United Nations Office on Drugs and Crime- UNODC) 2019 yılında yayınladığı "Kadınların ve Kız Çocuklarının Cinsiyetine Bağlı Olarak Öldürülmesi Üzerine Küresel Çalışma (Global Study On Homicide Gender-Related Killing of Women and Girls)" başlıklı raporda, dünya genelinde kadınların ve kız çocuk cinayetlerinin yüzde 64'ünün aile ve yakın ilişki kurulan kişiler tarafından işlendiği açıklanmıştır (United Nations Office on Drugs and Crime [UNODC], 2019). Türkiye'de 1 Ocak 2020 - 1 Temmuz 2020 aralığında işlenen 115 kadın cinayetinin şüphelilerinin yüzde 66'sının aile üyelerinden oluştuğu görülmektedir. Altı aylık dönemde işlenen kadın cinayetlerinin \%40'ının şüphelisi eşleri, \%23'ünün şüphelisi aile üyeleri, \%3'ünün ise akrabalarıdır. Bu cinayetlerde aile üyesi olmayan şüphelilerin yüzde 22 'si sevgili ya da erkek arkadaş, yüzde 8'i ise eski eştir. Türkiye'deki kadın cinayeti şüphelilerinin yüzde 96'sının hayatının bir döneminde dahi olsa kadının yakından tanıdığı, hayatını paylaştığı ve güven ilişkisi kurduğu kişilerden oluştuğu görülmektedir (İçişleri Bakanlığı İç Güvenlik Stratejileri Dairesi Başkanlığı, 2020, s.38).

\section{Mağdurların Demografik Özellikleri}

Türkiye'de 2020 yılının ilk altı ayında hayatını kaybeden kadınlar çoğunlukla 26 yaş üzeri, evli ve çocukludur. Bu dönemde hayatını kaybeden kadınların medeni durumları incelendiğinde, 60' $ı$ ın evli, 22'sinin bekâr, 18'inin boşanmış olduğu görülmektedir (İçişleri Bakanlığı İç Güvenlik Stratejileri Dairesi Başkanlığı, 2020, s.36). Sosyo-ekonomik profilleri ve meslekleri ele alındığında, maruz kaldıkları şiddet sebebiyle hayatını kaybeden kadınların, yüzde 17 'sinin düzenli bir gelire sahip olması, $\% 57$ 'sinin ise bir gelirinin olmaması nedeniyle ekonomik açıdan ailesine veya eşine bağımlı olması dikkat çekicidir. Bu durum, cinayete varan fiziksel şiddetin yanı sıra kadınların ekonomik ve duygusal şiddeti yaşamış olabileceklerine işaret etmektedir. Çalışan kadınların \%2'si akademik bir formasyon gerektiren 
bir işte çalışırken, yüzde 15 'i çoğunlukla usta çırak ilişkisi içinde öğrenilen, özel eğitim gerektirmeyen işlerde çalışmaktadır. Bu kadınlardan lisans düzeyinin altında eğitim alanların oranı \%42 iken, mesleki bilgisi olmayanların oranı \%37'dir (İçişleri Bakanlığı İç Güvenlik Stratejileri Dairesi Başkanlığı, 2020, s.37).

\section{Türkiye'de Kadına Yönelik Şiddetle Mücadele}

Kadına yönelik şiddetle mücadele, cinsiyet temelli şiddete karşı bir direnç oluşturmayı ve şiddeti dönüştürmeye yönelik mücadele yöntemlerini kapsamaktadır. Kadına yönelik şiddetin fiziksel, ekonomik ve psikolojik şiddet gibi boyutlarına, teknolojinin gelişmesi ile birlikte bir de özellikle sosyal medya ve internet üzerinden gerçekleşen dijital şiddet eklenmiştir.

Türkiye'de kadına yönelik şiddetle mücadelenin tarihsel bağlamına bakıldığında, Çankırı'da 1987 yılında eşinden fiziksel şiddet gören bir kadının açtı̆̆ davayı reddeden hâkime kadınların açtıkları manevi tazminat davası ve "Dayağa Hayır" yürüyüşü, Türkiye'de kadınların aile içi şiddete karşı başlattıkları mücadelenin başlangıcı olarak görülmektedir. Bu yürüyüş, kadınlara uygulanan şiddete karşı ilk kez kadınların bir araya gelerek topluluk oluşturmaları açısından önem taşımaktadır (Yıldırım, 1998, s.37).

1980'li yıllarda kamusal alanda seslerini duyurmaya başlayan ve daha çok devlet karşıtı söylemlerle devletle işbirliğini benimsemeyen kadınlar, 1990'l yıllardan itibaren ise devlet kurumları ve mekanizmaları ile işbirliği yaparak kadına yönelik şiddete karşı mücadeleyi sistematik ve yaygınlaştırilmış bir mücadele haline dönüştürmeye çalışmıştır (Altınay ve Arat, 2007, s.17). 1990'lı yıllarda kadına yönelik şiddete karşı verilen mücadele, 2000'li yıllarda gerçekleştirilen önemli hukuksal reformların zeminini hazırlamıştır. 4320 sayılı Aileyi Koruma Kanunu, yeni Medeni Kanun, yeni Türk Ceza Kanunu, 5393 sayılı Belediye Kanunu ve Temmuz 2006'da yayımlanan Başbakanlık Genelgesi, kadına yönelik şiddetle mücadelede reform niteliğinde düzenlemeler içermektedir. Kadına yönelik şiddete karşı devlet ve sivil toplum örgütlerinin işbirliği yaparak mücadele etmeye başlaması, toplumsal farkındalığın ve duyarlılığın sağlanmasına katkı sunmuştur (Altınay ve Arat, 2007).

Kadınların gördükleri şiddetten kimseye bahsetmeme eğilimini ortaya koyan araştırmalar, kadınların şiddete karşı bir yalnızlık algısına sahip ol- 
duklarına işaret etmektedir. Kadına yönelik şiddetle mücadeleyi odağına alan sivil toplum örgütlerinin sayısının artması, devlet kurumlarının farkındalıklarının yükselmesi, yasal düzenlemelerle kadına yönelik şiddetle mücadelenin desteklenmesi ile bu yalnızlık algısının kısmen değişmeye başladığı tespiti yapılabilir.

Kadınlar, daha çok şiddete dayanma güçlerinin tükendiğini, ölüm tehdidi ya da korkusu ile karşı karşıya kaldıklarında veya çocuklarının tehdit altında olduğunu hissettiklerinde yardım isteme ihtiyacı duymaktadır. Altınay ve Arat'ın (2007, s.93) araştırmasına göre, eşinin kendisine fiziksel şiddet uygulaması halinde kadınların yüzde $24^{\prime}$ ü farklı nedenlerle bir şey yapamayacağını ifade ederken, komşusunun fiziksel şiddete uğraması halinde elinden bir şey gelmeyeceğini belirtenlerin oranı ise yüzde 45 'e kadar yükselmektedir. Kendisi fiziksel şiddete uğrarsa polise gideceğini söyleyenlerin oranı yüzde 5'te kalırken, komşusunun fiziksel şiddet görmesi halinde polisi arayacağını bildirenlerin oranı yüzde 13'tür (Altınay ve Arat, 2007, s.93). Kadına yönelik şiddetle mücadele kapsamında, pek çok yasal düzenleme yapılmış olsa bile kadınların çoğunluğunun bu düzenlemeden ve haklarından habersiz olması da (Ergönen vd., 2009) mücadeleyi sekteyi uğratmakta, kadınların haklarını öğrenmesi ve şiddet görmesi halinde nereye, nasıl başvuracağı konusunda bilgi sahibi olması için de geniş çaplı çalışmaların yapilması gerekmektedir.

Şiddet Önleme ve İzleme Merkezleri (ŞÖNIM) Türkiye'de aile içi şiddetle mücadele etmek maksadıyla 6284 sayılı Ailenin Korunması ve Kadına Yönelik Şiddetin Önlenmesine Dair Kanun kapsamında kurulmuştur. 2020 yılı sonunda Türkiye'nin 81 ilinde, 81 ŞÖNIM yedi gün 24 saat hizmet vermektedir (Türkiye'de Şiddeti Önleme ve İzleme Merkezleri, 2021). İlk kabul ve konukevleri ile Alo 183 ŞÖNİM bünyesinde faaliyet göstermektedir. Yine 2020 yılı sonu itibariyle Türkiye'de 145 konukevinde şiddete uğrayan kadınlar, çocuklarıyla beraber belirli bir süre kalabilmektedir. Konukevlerinde sadece barınma değil, psikolojik ve sosyal destek hizmetleri de kadınlara sunulmaktadır (Demirdirek ve Şener, 2014, s.29). Ayrıca, 347 Sosyal Hizmet Merkezi de dâhil olmak üzere 428 yerde Kadın Hizmetleri İrtibat noktaları ŞÖNIMM'ler ve Kadın Konukevlerine ilave olarak kurulmuştur.

İçişleri Bakanlığı Kadın Acil Destek (KADES) uygulamasını 2018 yılında faaliyete geçirmiştir. Uygulamayı, 2020 yılı sonuna kadar 1 mil- 
yondan fazla kişi cep telefonlarına indirmiş, 68 binden fazla kadın bu uygulama aracılığ 1 ile ihbarda bulunmuştur (TRT Haber, 2 Ocak 2021). 2018'den 15 Nisan 2021 tarihine kadar ise KADES uygulaması 2 milyon 106 bin 437 kişi tarafından indirilmiştir (İçişleri Bakanlığı, 15 Nisan 2021), 9 Nisan 2021 tarihine kadar 109 bin 563 kadın bu uygulama aracılığıyla ihbarda bulunmuş, 56 bin 788 asıllı ihbara müdahale edilmiştir (İçişleri Bakanlığı, 9 Nisan 2021).

Kadına yönelik şiddetle mücadelede başarıya ulaşılmasında devlet kurumlarından güçlü bir destek beklenmektedir. Kadınların yüzde 60 ile yüzde 74'ü devletin erkeklerin eğitilmesini sağlayarak, konukevlerinin say1sını artırarak, bu konuda çalışan sivil toplum kuruluşlarını destekleyerek, ağır cezalar verilmesine imkân tanıyan kanuni düzenlemeler yaparak kadınların maruz kaldığ 1 şiddeti engelleyebileceği fikrine sahiptir (Altınay ve Arat, 2007, s.100). Kadınların yüzde 85'i konukevlerinin sayısının yeterli olmadığını belirtirken, yüzde 87'si vergilerinin konukevleri açmak için harcanmasını uygun görmektedir. Kadınların yüzde 92'si kadına fiziksel şiddet uygulayan erkeklere mahkemelerin ceza vermesini istemektedir (Altınay ve Arat, 2007, s.101-102).

Kadına yönelik şiddetle mücadelede, yönetime, belediyelere, devlet kurumlarına, yasalara ve mahkemelere sorumluluk yüklenmektedir. Bu kapsamda, 2019 yılında 40 bin civarı kolluk personeli aile içi ve kadına yönelik şiddetle mücadele eğitimi alırken, bu sayı 2020 yılında 153 bin 428 olmuştur (İçişleri Bakanlığı, 9 Nisan 2021). Ayrıca, elektronik kelepçe izleme merkezi İçişleri Bakanlığı Güvenlik ve Acil Durumlar Koordinasyon Merkezi (GAMER) bünyesinde kurulmuştur (İçişleri Bakanlığı, 15 Nisan 2021). Pilot olarak 15 ilde yürütülen, 15 Ocak 2021'de 81 ilde yayginlaştırılan elektronik kelepçe uygulaması ile 9 Nisan 2021 tarihinde, polis ve jandarma bölgelerinde, kadına yönelik şiddet içerdiği tespit edilen 121 vakanın takibinin kesintisiz yapıldığı açıklanmıştır (İçişleri Bakanlığı, 9 Nisan 2021). Emniyet ve jandarma teşkilatlarında daha önce illerde faaliyet gösteren "Aile İçi ve Kadına Karşı Şiddetle Mücadele Büro Amirliği" ilçe seviyesine kadar yaygınlaştırılmış ve yeni birimler kurulmuştur (Hürriyet Gazetesi, 19 Nisan 2021). Bu birimlerde 8 bin personel görev yapmaktadır (İçişleri Bakanlığı, 15 Nisan 2021). "Aile İçi ve Kadına Karşı Şiddet Olayları Kayıt ve Risk Değerlendirme Formu" güncellenmiş, yeni formlarda kişilerin risk düzeyleri, kırmızı (çok yüksek risk), turuncu (yüksek risk), sarı 
(orta risk), gri (düşük risk) olmak üzere dört basamakta kategorize edilmiştir (İçişleri Bakanlığı, 15 Nisan 2021).

Kadınların, kadına yönelik şiddetle mücadelede devlet kurumlarına yüklediği sorumluluğa cevap verebilmek amaciyla 2006 yılından başlayarak dört yıllık Kadına Yönelik Şiddetle Mücadele Ulusal Eylem Planları hazırlanmıştır. Kadına Yönelik Şiddetle Mücadele İl Eylem Planları "Kadına Yönelik Şiddetle Mücadele 3. Ulusal Eylem Planı" çerçevesinde, 81 ilde yürürlüğe konulmuştur. Ayrıca, İl Koordinasyon, İzleme ve Değerlendirme Komisyonları oluşturulmuştur. 1 Temmuz 2021'de "Şiddete sıfır tolerans" ilkesi ile "Kadına Yönelik Şiddetle Mücadele 4. Ulusal Eylem Planı" açıklanmıştır. "Politika ve koordinasyon", "Adalete erişim ve mevzuat", "Toplumsal farkındalık", "Veri ve istatistik ve "Koruyucu önleyici hizmetler" olmak üzere beş ana hedefi içeren plan 2021-2025 yıllarını kapsamaktadır. Plan, ayrıca 28 strateji ve 227 faaliyet içermektedir (Kadına Yönelik Şiddetle Mücadele IV. Ulusal Eylem Planı 2021-2025, 1 Temmuz 2021). 75 maddeden oluşan "2020-2021 Kadına Yönelik Şiddetle Mücadele Koordinasyon Planı İçişleri Bakanlığı, Aile, Çalışma ve Sosyal Hizmetler Bakanlığı, Milli Eğitim Bakanlığı, Sağlık Bakanlığı, Adalet Bakanlığı ve Diyanet Başkanlığı'nca müşterek hazırlanmıştır (Aile, Çalışma ve Sosyal Hizmetler Bakanlığı, 2019).

\section{Yöntem}

\section{Araştırma Deseni}

Türkiye'de kadına yönelik şiddetle mücadele algısını ölçmek, dizilerin bireylerin kadına yönelik şiddet algısı üzerindeki etkilerini incelemek maksadıyla nicel araştırma deseni uygulanmıştır. Bilginin deneysel yöntemlerle elde edilebileceği esasına dayanan pozitivist yaklaşımı benimseyen nicel araştırma deseninin tercih edilme nedeni, örneklem üzerinden yapılan çıkarımların araştırma evrenine genellenebilme imkânını tanımasıdır (Creswell, 2009). 


\section{Verilerin Toplanmas1}

Araştırma sorularına yanıt verebilmek için İç Güvenlik Strateji Dairesi Başkanlığınca yürütülen bir araştırma projesi kapsamında anket veri toplama yöntemi ile elde edilen veriler gerekli kurumsal izinler alınarak kullanılmıştır. Dolayısıyla çalışmamızda ikincil veriler kullanılmıştır. İkincil verileri kullanmanın en önemli avantajı bir araştırmacı tarafından elde edilmesi mümkün olmayan kaliteli veriden istifade edilmesidir (Goodwin, 2012). Kaynak ve zaman tasarrufu ikincil veri kullanımının bir başka avantajıdır (Bryman, 2008).

\section{Analitik Strateji}

Veri Analizi: Araştırmamızın birinci amacı Türkiye'deki kadına yönelik şiddetle mücadele algısının ölçülmesiydi. Bu kapsamda, betimsel istatistiklerin yanı sıra ilişkisel analiz, bireylerin demografik özellikleri (cinsiyet, yaş, eğitim durumu ve medeni durum) ile kadına yönelik şiddetle mücadele algisı arasındaki ilişkileri incelemek amacıyla kullanılmıştır. Kruskal Wallis $\mathrm{H}$ testi grup ortalamaları arasında istatistiksel olarak anlamlı bir farklılık olup olmadığını ölçmek, Mann-Whitney U testi de iki grup ortalamalarını karşılaştırmak maksadıyla kullanılmıştır. Bu iki test non-parametrik testler olup, normal dağılım göstermeyen kategorik değişkenler arasındaki ilişkileri incelemek için kullanılmaktadır (McKnight ve Najab, 2010).

Araştırmamızın ikinci amacı ise, dizilerin kadına yönelik şiddet algısı üzerindeki etkilerinin ölçülmesiydi. Bu amaca ulaşmak için, sıralı (ordinal) lojistik regresyon analiz kullanılmıştır. Sıralı lojistik regresyon analizi bağımlı değişken ikiden fazla kategoriye sahip olduğunda uygulanan çok değişkenli bir analiz yöntemidir (Harrell, 2015). Bu yöntemde, modelde yer alan diğer bağımsız değişkenlerin etkileri sıfırlanırken, incelenen bağımsız değişkenin bağımlı değişken üzerinde yaptığı etki incelenmektedir (Liu ve Koirala, 2012). 


\section{Örneklem}

İç Güvenlik Stratejileri Dairesi Başkanlığınca yürütülen proje kapsamında 26 büyükşehir merkezinde 18 yaş üstü 1130 birey çalışmaya katılmıştır. Katılımcıların demografik özellikleri Tablo 2' de yer almaktadır.

Tablo 2. Katılımcılarn Demografik Özellikleri

\begin{tabular}{lll}
\hline & N & $\%$ \\
\hline Cinsiyet & 638 & \\
Kadın & 492 & 56,5 \\
Erkek & & 43,5 \\
Yaş & 228 & \\
$18-24$ & 324 & 20,2 \\
$25-34$ & 239 & 28,7 \\
$35-44$ & 161 & 21,2 \\
$45-54$ & 178 & 14,2 \\
55 ve üzeri & & 15,8 \\
Eğitim Durumu & 321 & 28,4 \\
Diplomasız ve İkokul Mezunu & 181 & 16,0 \\
Ortaokul Mezunu & 416 & 36,8 \\
Lise Mezunu & 212 & 18,8 \\
Üniversite ve Yüsek Okul Mezunu & & \\
Medeni Durum & 806 & 71,3 \\
Evli & 298 & 26,4 \\
Bekar & 26 & 26 \\
Boşanmş/Dul & 1130 & 100,0 \\
Toplam & & \\
\hline
\end{tabular}

\section{Bağımlı Değişken}

Kadına Yönelik Şiddetle Mücadele Algısı: Kadına yönelik şiddetle mücadele algısını ölçmek maksadıyla katılımcılara "Kadına yönelik şiddetle mücadeleyi ne derece yeterli buluyorsunuz?" sorusu sorulmuştur. Katılımciların düşünceleri 5'li Likert ölçeği (1= Çok yetersiz buluyorum, $2=$ Yetersiz buluyorum, $3=\mathrm{Ne}$ yeterli Ne yetersiz buluyorum, $4=$ Yeterli buluyorum, $5=$ Çok yeterli buluyorum) ile ölçülmüştür.

Kadına Şiddet Temalı Dizilerin Kadına Şiddet Olgusuna Etkisi: Kadına şiddet temalı dizilerin kadına şiddet olgusu üzerindeki etkilerini ölçmek maksadıyla katılımcılara 6 soru (kadına şiddet ile karşılaşıldığında polise ihbar edilmesi, ekonomik özgürlüğü olmayan kadınlara karşı sempati ve yardım isteği uyandırması, kadınlara şiddetle mücadele edebilmeleri için güven vermesi, şiddet gören kadın ve çocukların psikolojik sıkıntıları hak- 
kında bilgi vermesi, toplumda kadına şiddete karşı birleşme konusunda teşvik etmesi, kadına şiddetin suç olduğunu anlatması) sorulmuştur. Her bir soruda belirtilen ifadeye katılım ifadesi 5'li Likert ölçeği (1=Kesinlikle katılmiyorum, 2=Katılmıyorum, 3=Ne katılıyorum ne katılmıyorum, 4= Katılıyorum, $5=$ Kesinlikle katılıyorum) ile ölçülmüştür.

\section{Bağımsız Değişken}

Dizi İzleme Sıklı̆̆ı: Katılımcıların dizi izleme sıklığı 5'li Likert (1=günde 1 saat, $2=$ günde 2 saat, $3=$ günde 3 saat, $4=$ günde 4 saat, $5=$ günde 5 saat ve üzeri) ile ölçülmüştür.

İzlenen Dizi Türü: Sıklıkla izlenen dizi türünün bireylerin kadına yönelik şiddetle mücadele algısına etkisini ölçmek amacıyla, $\mathrm{d}$ dizi türü (şiddet içerikli, polisiye, hapishane temalı, savaş temalı, sağlık temalı ve kadına şiddet temalı) bağımsız değişken olarak regresyon modeline dâhil edilmiştir.

Demografik Özellikler: Cinsiyet, yaş, eğitim durumu ve medeni durum analizlere dâhil edilmiştir.

\section{Bulgular}

\section{Yayın ve Yerli Dizi İzleme Sıklığı}

Televizyon ve diğer platformlar üzerinden yayın izleme sıklığı incelendiğinde, katılımclların $\% 35,4^{\prime}$ ü günde 3 saat, $\% 26,1^{\prime}$ i günde 4 saat ve $\% 23,1^{\prime} i$ günde 5 saat ve üzerinde televizyon yayını izlediğini ifade etmiştir. Katılımcıların dizi izleme sıklığı incelendiğinde ise, günde 3 saat dizi izlediğini belirten bireylerin oranı $\% 45,7$ günde 4 saat dizi izleyenlerin oran $\% 12,7$ ve günde 5 saatten fazla yerli dizi izleyenlerin oranı \%15,9'dür (Tablo 3). Bir başka ifadeyle katılımcıların \%84,6'sı günde 3 saatten fazla televizyon yayını izlediğini, \%74,3'ü de günde 3 saatten fazla süreyle yerli dizi izlediğini ifade etmiştir. 
Tablo3. Yayın ve Yerli Dizi İzleme Sıklığı

\begin{tabular}{lllll}
\hline & \multicolumn{2}{l}{ Yayın İzleme Sıklı̆̆ } & \multicolumn{2}{l}{ Yerli Dizi İzleme Sıklı̆ı } \\
\cline { 2 - 5 } & $\mathbf{N}$ & $\mathbf{\%}$ & $\mathbf{N}$ & $\mathbf{\%}$ \\
\hline Günde 1 saat & 79 & 7,0 & 124 & 11,0 \\
Günde 2 saat & 95 & 8,4 & 166 & 14,7 \\
Günde 3 saat & 400 & 35,4 & 516 & 45,7 \\
Günde 4 saat & 295 & 26,1 & 144 & 12,7 \\
Günde 5 saat ve üzeri & 261 & 23,1 & 180 & 15,9 \\
Toplam & 1130 & 100,0 & 1130 & 100,0 \\
\hline
\end{tabular}

Katılımcıların \%54'ü kadına yönelik şiddetle mücadeleyi yetersiz bulduğunu ifade ederken, kadına yönelik şiddetle mücadeleyi yeterli bulduğunu ifade edenlerin oranı \%25,7 olmuştur (Tablo 4).

Tablo 4. Katılımcıların Kadına Yönelik Şiddetle Mücadele Algısı

\begin{tabular}{lll}
\hline & $\mathbf{N}$ & \% \\
\hline Çok yetersiz buluyorum & 286 & 25,3 \\
Yetersiz buluyorum & 328 & 29,0 \\
Ne yeterli Ne yetersiz buluyorum & 226 & 20,0 \\
Yeterli buluyorum & 270 & 23,9 \\
Çok yeterli buluyorum & 20 & 1,8 \\
Toplam & 1130 & 100,0 \\
\hline
\end{tabular}

Kadına yönelik şiddetle mücadelede cinsiyet farklılıkları incelendiğinde, erkeklerin sira ortalamasinin ( $\left.\overline{\mathrm{x}_{\text {sira }}}=653,52\right)$ kadınların sira ortalamasından ( $\overline{\text { ssra }}=497,62)$ daha yüksek olduğu görülmektedir. Bu sonuç $\mathrm{p}<0,001$ seviyesinde istatistiksel olarak anlamlıdır (Tablo, 5).

Tablo 5. Kadına Yönelik Şiddetle Mücadele Algısında Cinsiyet Farklılıklar

\begin{tabular}{llllll}
\hline Grup & $\mathbf{N}$ & Sira Ortalaması & Sira Toplamı & U & P \\
\hline Kadın & 638 & 497,62 & 317481,00 & \multirow{2}{*}{11364,000} & \multirow{2}{*}{$0,001^{*}$} \\
Erkek & 492 & 653,52 & 321534,00 & & \\
\hline
\end{tabular}

Kadına yönelik şiddetle mücadele algısında cinsiyet farklılıkları, çapraz tablolar vasitasıyla incelendiğinde de benzer şekilde cinsiyet farklılıkları görülmektedir $(\chi 2=86,3 ; p<0.001)$. Kadınların \%33,1'i kadına yönelik şiddetle mücadelenin çok yetersiz olduğuna inanırken, bu oran erkeklerde $\% 15,2$ 'dir. Benzer şekilde, kadınların \%32'si kadına yönelik şiddetle mücadelenin yetersiz olduğunu düşünürken, erkeklerin \%25,2'si bu görüşü paylaşmaktadır (Tablo 6). 
Tablo 6. Kadına Yönelik Şiddetle Mücadele Algısında Cinsiyet Farklılıkları

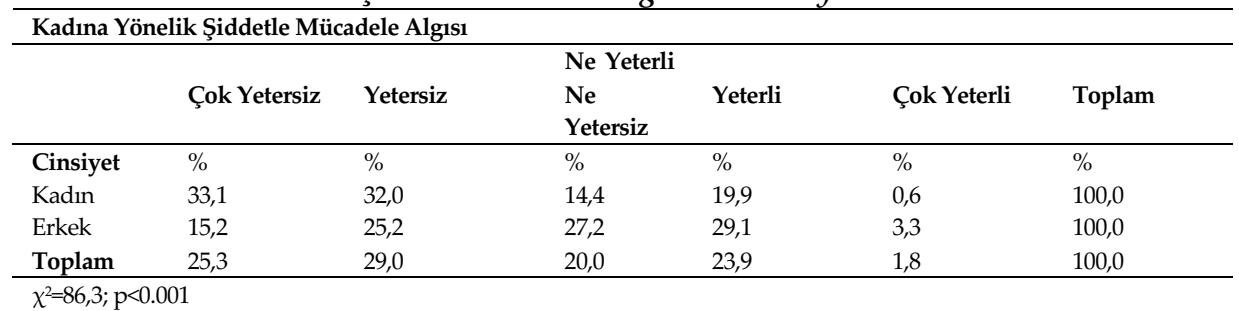

Kadına yönelik şiddetle mücadele algısında yaş grupları arasında bir farklılık olup olmadığını incelemek için öncelikle Kruskal Wallis H testi uygulanmıştır. Bu test sonucuna göre yaş kategorilerinin kadına yönelik şiddetle mücadele algıları ortalamalarında istatistiksel olarak anlamlı farklıliklar bulunmaktadır ( $\mathrm{H}(\mathrm{sd}=4, \mathrm{n}=1130)=23,943, \mathrm{p}<0,001)$ (Tablo 7).

Tablo 7. Kadına Yönelik Şiddetle Mücadele Algısında Yaş Farklılıkları

\begin{tabular}{llllll}
\hline Yaş Kategorileri & N & Sira Ortalamasi & sd & Kruskal-Wallis H & p \\
\hline $18-24$ & 228 & 540,00 & & & $0,001^{*}$ \\
$25-34$ & 324 & 605,77 & 4 & 23,943 & \\
$35-44$ & 239 & 597,40 & & & \\
$45-54$ & 161 & 573,47 & & & \\
55 ve üstü & 178 & 474,81 & & & \\
Toplam & 1130 & & & & \\
\hline$* 00,001$ & & & &
\end{tabular}

Kruskal Wallis test sonucu yaş kategorileri arasında kadına yönelik şiddetle mücadele algısı ortalamalarında farklılıklar bulunduğunu göstermesini müteakip, yaş grupları arasındaki ikili farklılıkları incelemek için bir dizi Mann-Whitney U testi yapılmıştır. İstatistiksel olarak $p<0,05$ ve $p<0,1$ seviyesinde anlamlı olan test sonuçları Tablo 8 ' de görülmektedir.

Mann-Whiteny $\mathrm{U}$ test sonuçlarına göre, 18-24 yaş aralığındaki bireylerin sıra ortalaması ( $\overline{\text { sira }}=258,42 ; \mathrm{p}<0,05), 25-34$ yaş aralığındaki bireylerden ( $\overline{\text { sira }}$ =289,22; $\mathrm{p}<0,05)$ daha düşüktür. Benzer şekilde, 18-24 yaş aralığındaki bireyleri sıra ortalaması ( $\left.\overline{\mathrm{x}_{\text {srra }}}=222,24 ; \mathrm{p}<0,1\right) 35-44$ yaş aralığındaki kişilerin sıra ortalamasından ( $\left.\overline{\mathrm{x}_{\text {sira }}}=245,22 ; \mathrm{p}<0,1\right)$ daha düşüktür. Fakat 55 yaş ve üzeri bireylerin sıra ortalaması ( $\left.\overline{\mathrm{x}_{\text {srra }}}=191,63 ; \mathrm{p}<0,1\right) 18$-24 yaş aralığındaki kişilerin sıra ortalamasından $(\overline{\mathrm{x} s r r a}=212,77 ; \mathrm{p}<0,05)$ daha düşüktür. 
Diğer yandan, 25-34, 35-44 ve 45-54 yaş gruplarına ait bireylerin kadına yönelik şiddetle mücadele algısı sıra ortalamalarında $p<0,1$ seviyesinde bile anlamlı bir farklılik yoktur.

Son olarak, 55 yaş üstü bireylerin kadına yönelik şiddetle mücadele alg1 sıra ortalaması diğer yaş gruplarının tamamından düşüktür (Tablo 8).

Tablo 8. Kadına Yönelik Şiddetle Mücadele Algısında Yaş Grupları Farklılıkları

\begin{tabular}{|c|c|c|c|c|c|}
\hline Grup & $\mathbf{N}$ & Sira Ortalaması & Sira Toplamı & Mann-Whitney U & $\mathbf{P}$ \\
\hline $18-24$ & 228 & 258,42 & 58920,00 & \multirow[b]{2}{*}{32814,000} & \multirow[b]{2}{*}{$0,021^{* *}$} \\
\hline $25-34$ & 324 & 289,22 & 93708,00 & & \\
\hline $18-24$ & 228 & 222,24 & 50671,00 & \multirow{2}{*}{24565,000} & \multirow{2}{*}{$0,057^{* * *}$} \\
\hline $35-44$ & 239 & 245,22 & 58607,00 & & \\
\hline $18-24$ & 228 & 212,77 & 48510,50 & \multirow{2}{*}{18179,500} & \multirow{2}{*}{$0,061^{* * *}$} \\
\hline $55+$ & 178 & 191,63 & 34110,50 & & \\
\hline $25-34$ & 324 & 272.49 & 88286.00 & \multirow{2}{*}{22036.000} & \multirow{2}{*}{$0,001^{*}$} \\
\hline $55+$ & 178 & 213.30 & 37967.00 & & \\
\hline $35-44$ & 239 & 228.26 & 54553.50 & \multirow{2}{*}{16668.500} & \multirow{2}{*}{$0,001^{*}$} \\
\hline $55+$ & 178 & 183.14 & 32599.50 & & \\
\hline $45-54$ & 161 & 186.32 & 29997.00 & \multirow{2}{*}{11702.000} & \multirow[t]{2}{*}{$0,002^{*}$} \\
\hline $55+$ & 178 & 155.24 & 27633.00 & & \\
\hline
\end{tabular}

${ }^{*} p<0,001{ }^{* *} p<0,05 * * * 0<0,1$

Kruskal-Wallis ve Mann-Whitney testlerinin ön koşulllarından biri, grup sayıları arasında çok büyük farklılıklar olmamasıdır. Katılımcıların medeni durumların belirten gruplar arasında önemli oranda farklılık olduğu için ( $\eta_{\text {evil }}=806, \eta_{\text {bekar }}=298, \eta_{\text {boşanmıs/dul }=26)}$ medeni durum ve kadına yönelik şiddetle mücadele algısı arasındaki ilişki incelenememiştir.

Eğitim durumu ve kadına yönelik şiddetle mücadele algısı arasındaki ilişki incelendiğinde, Kruskal Wallis test sonuçları eğitim durumu kategorilerinin sıra ortalamaları arasında istatistiksel olarak anlamlı bir farklılık olduğunu göstermektedir (Tablo 9).

Tablo 9. Kadına Yönelik Şiddetle Mücadele Algısında Ĕ̆itim Durumu Farklılıkları

\begin{tabular}{llllll}
\hline Eğitim Durumu & N & Sira Ortalaması & sd & Kruskal-Wallis H & p \\
\hline Diplomasız ve İlkokul & 321 & 572,80 & & & \\
Mezunu & 181 & 516,06 & & & $0,029^{*}$ \\
Ortaokul Mezunu & 416 & 564,81 & 3 & 9,032 & \\
Lise Mezunu & 212 & 598,02 & & & \\
Üniversite ve Yüsek Okul & & & & \\
Mezunu & & &
\end{tabular}


Katılımcların eğitim durumu kategorileri arasında istatistiksel olarak anlamlı bir farklılık olduğu görüldükten sonra, bir seri Mann-Whitney U testi icra edilmiştir. Diplomasız veya ilkokul mezunu bireylerin sıra ortalaması ( $\left.\overline{\mathrm{x}_{\text {sra }}}=236,70 ; \mathrm{p}<0,05\right)$, ortaokul mezunlarının sira ortalamasından daha düşüktür ( $\left.\overline{\mathrm{x}_{\text {srra }}}=277,75 ; \mathrm{p}<0,05\right)$. Üniversite ve lisansüstü eğitim alan bireylerin sıra ortalamaları, diğer eğitim kategorilerinden mezun bireylerin sira ortalamalarından daha düşüktür (Tablo 10).

Tablo 10. Kadına Yönelik Şiddetle Mücadele Algısında Eğitim Durumu Farklılıkları

\begin{tabular}{|c|c|c|c|c|c|}
\hline Grup & $\mathbf{N}$ & $\begin{array}{l}\text { Sira Ortalama- } \\
\text { s1 }\end{array}$ & Sira Toplamı & $\begin{array}{l}\text { Mann-Whitney } \\
\text { U }\end{array}$ & $\mathbf{P}$ \\
\hline $\begin{array}{l}\text { Diplomasız ve İlkokul Mezu- } \\
\text { nu }\end{array}$ & 321 & 236,70 & 75979,50 & 24298,500 & $0,002^{* *}$ \\
\hline Ortaokul Mezunu & 181 & 277,75 & 50273,50 & & \\
\hline $\begin{array}{l}\text { Diplomasız ve İlkokul Mezu- } \\
\text { nu }\end{array}$ & 321 & 358,03 & 114928,50 & 63247,500 & 0,205 \\
\hline Lise Mezunu & 416 & 377,46 & 157024,50 & & \\
\hline $\begin{array}{l}\text { Diplomasız ve İlkokul Mezu- } \\
\text { nu }\end{array}$ & 321 & 280,94 & 90182,50 & & \\
\hline $\begin{array}{l}\text { Üniversite ve Yüsek Okul } \\
\text { Mezunu }\end{array}$ & 212 & 245,89 & 52128,50 & 29550,500 & $0,008^{* *}$ \\
\hline Ortaokul Mezunu & 181 & 227,75 & 41223,00 & & \\
\hline $\begin{array}{l}\text { Üniversite ve Yüsek Okul } \\
\text { Mezunu }\end{array}$ & 212 & 170,75 & 36198,00 & 13620,000 & $0,001^{*}$ \\
\hline Lise Mezunu & 416 & 333,06 & 138554,50 & & \\
\hline $\begin{array}{l}\text { Üniversite ve Yüsek Okul } \\
\text { Mezunu }\end{array}$ & 212 & 278,07 & 58951,50 & 36373,500 & $0,001^{*}$ \\
\hline
\end{tabular}

${ }^{*} p<0,001{ }^{* *} p<0,05$

\section{Kadına Yönelik Şiddet Temalı Dizilerin Kadına Şiddet Olgusuna Etkisi}

Kadına yönelik şiddet temalı dizilerin kadına şiddet olgusu, üzerindeki etkisini ölçmek için sorulan 6 soruya katılımcların verdikleri yanıtlara ait betimleyici istatistikler Tablo 11'de sunulmaktadır. Katılımcların \%74'ü kadına yönelik şiddet temalı dizilerin, kadına yönelik şiddetin bir suç olduğunu öğrettiği fikrine katılırken, \%69,7'si kadına yönelik şiddetle mücadele konusunda toplumu birleşmeye teşvik ettiği düşüncesine katılmıştır. Katılımcıların \%76,4'ü kadına yönelik şiddet temalı dizilerin, şiddet gören kadın ve çocukların psikolojik sıkıntıları hakkında bilgi verdiği düşüncesine katıldığını belirtmiştir. Ayrıca, dizi izleyicilerinin \%56,1'i kadına yönelik şiddet temalı dizilerin kadınlara şiddetle mücadele edebilmeleri için güven verdiği 
fikrine katılmıştır. Dizilerin, ekonomik özgürlüğü olmayan kadınlara karşı sempati ve yardım isteği uyandırdığını belirten katılımcıların oranı \%71,5 iken, kadına yönelik şiddet ile karşılaşıldığı zaman, polise ihbar edilmesi ve müdahale edilmesi gerektiğini hissettirdiğini düşünenlerin oranı $\% 56,8^{\prime}$ dir.

Sorulara verilen cevapların geneli incelendiğinde, kadına yönelik şiddet temalı dizilerin, şiddet olgusu ve kadına yönelik şiddetle mücadele yöntemleri konusunda hakkında öğretici olduğunu, kadına yönelik şiddet sorunu hakkında toplumsal farkındalığa katkı sağladığını söylemek mümkündür.

\section{Tablo 11. Kadına Şiddet Temalı Dizilerin Kadına Şiddet Olgusuna Etkisi}

\begin{tabular}{|c|c|c|c|c|c|}
\hline & 1 & 2 & 3 & 4 & 5 \\
\hline & $\%$ & $\%$ & $\%$ & $\%$ & $\%$ \\
\hline $\begin{array}{l}\text { Etrafımızda kadına şiddet ile karşılaştı̆̆ımız zaman polise ihbar edilmesi ve } \\
\text { müdahale edilmesi gerektiğini hissettiriyor }\end{array}$ & 2,6 & 24,8 & 15,9 & 18,3 & 38,5 \\
\hline $\begin{array}{l}\text { Ekonomik özgürlüğü olmayan kadınlara karşı sempati ve yardım isteği uyan- } \\
\text { dırıyor }\end{array}$ & 1,9 & 7,1 & 19,6 & 40,1 & 31,4 \\
\hline Kadınlara şiddetle mücadele edebilmeleri için güven veriyor & 1,6 & 9,1 & 33,3 & 21,5 & 34,6 \\
\hline Şiddet gören kadın ve çocukların psikolojik sıkıntıları hakkında bilgi veriyor & 1,3 & 9,2 & 13,1 & 30,3 & 46,1 \\
\hline Toplumu kadına şiddete karşı birleşme konusunda teşvik ediyor & 1,3 & 10,2 & 18,7 & 30,1 & 39,6 \\
\hline Kadına şiddetin suç olduğunu anlatıyor & 1,0 & 6,1 & 18,9 & 27,5 & 46,5 \\
\hline
\end{tabular}

1=Kesinlikle katılmiyorum, 2=Katılmiyorum, 3=Ne katilıyorum ne katılmiyorum, 4= Katıllyorum, $5=$ Kesinlikle katıliyorum

\section{Yerli Dizilerin Kadına Yönelik Şiddet Algısı Üzerine Etkileri}

Yerli dizilerin kadına yönelik şiddet algısı üzerindeki etkisi sıralı regresyon analizi ile incelenmiştir. Modele dizi izleme sıklığı, şiddet, polisiye, hapishane, savaş, sağlık ve kadına yönelik şiddet temalı dizileri sıklıkla izleme ile demografik özellikler (cinsiyet, yaş, medeni durum ve eğitim durumu) bağımsız değişken olarak eklenmiştir. Model uyumu incelendiğinde modelin istatistiksel olarak anlamlı olduğu görülmektedir (-2 Log Likelihood= 2496, $653 \chi 2=412,217 \mathrm{p}<0,001$ ) (Tablo 12). Nagelkerke $\mathrm{R}^{2}$ değeri yerli dizileri sıklıkla izlemenin, kadına yönelik şiddet algısındaki değişimin \%32,4'ünü açıladığını göstermektedir.

Bağımsız değişkenlerin, kadına yönelik şiddet üzerindeki özgün etkileri incelendiğinde, dizi izleme sıklığı, şiddet içerikli, polisiye temalı, hapishane temalı ve kadına yönelik şiddet temalı dizileri sıklıkla izlemenin istatistiksel olarak anlamlı etkileri olduğu görülmüştür. Diğer yandan; savaş ve sağlık temalı dizileri sıklıkla izlemenin kadına yönelik şiddet algısı üzerinde ista- 
tistiksel olarak anlamlı bir etkisi ölçülmemiştir. Kadına yönelik şiddet algısinda demografik özelliklerden yaş ve cinsiyet farklılıkları gözlemlenirken, medeni durum ve eğitim durumunun istatistiksel olarak anlamlı bir etkisi görülmemiştir. İkili ilişkileri inceleyen analizlerde farklı eğitim kategorilerindeki bireylerin kadına yönelik şiddet algılarında bir farklılık gözlemlenmiş olsa da, çok değişkenli sıralı lojistik regresyon modelinde eğitim durumunun bir değişken olarak kadına yönelik şiddet üzerinde anlamlı bir etkisi görülmemiştir.

Dizi izleme sıklığının kadına yönelik şiddet algısı üzerindeki etkisi incelendiğinde, dizi izleme sıklığı azaldıkça bireylerin kadına yönelik şiddetle mücadeleyi başarılı görme oranları da azalmaktadır. Günde 1 saat dizi izlediğini ifade eden bireylerin, referans kategori olan günde 5 saat ve daha fazla dizi izleyenlere göre kadına şiddetle mücadeleyi başarılı görme ihtimalleri \%81 oranında azalmaktadır $(\exp (\beta) 1-0,19=0,81)$. Benzer şekilde günde 2 saat dizi izlediğini ifade eden bireylerin kadına şiddetle mücadeleyi başarılı görme ihtimalleri sıklıkla dizi izleyen referans kategoride yer alan bireylere oranla $\% 65$ daha azdır $(\exp (\beta) 1-0,30=0,35)$.

Yerli dizileri sıklıkla izlemenin, kadına yönelik şiddet algısı üzerindeki etkisi dizilerin temaları bazında incelendiğinde, şiddet temalı yerli dizileri sıklıkla izleyenlerin kadına şiddetle mücadeleyi başarılı bulma ihtimalleri izlemeyenlere göre $\% 43$ daha fazladır $(\exp (\beta)$ 1,43-1=0,43). Kadına yönelik şiddetle mücadele algısı üzerinde en fazla etkinin polisiye dizileri sıklıkla izlemek olduğu görülmektedir. Polisiye temalı dizileri izleyen bireylerin izlemeyenlere oranla kadına şiddetle mücadeleyi başarılı bulma ihtimalleri $\% 150$ daha fazladır (exp ( $\beta$ ) 2,50-1=1,50). Diğer yandan, hapishane temalı dizileri sıklıkla izlemek kadına yönelik şiddetle mücadeleyi başarılı bulma olasılığını \%72, kadına yönelik şiddet temalı dizileri sıkla izlemek de \%51 oranında arttırmaktadır (exp ( $\beta$ ) 1,72 ve 1,51 sırasıyla).

Ayrıca analiz sonuçlarına göre, kadınların, kadına yönelik şiddetle mücadeleyi başarılı bulma olasılıkları erkeklere oranla \%49 daha azdır (exp ( $\beta$ ) 1-0,51=0,49). Genç bireylerin, 55 yaş ve üstü bireylere oranla kadına şiddetle mücadeleyi daha başarılı gördüklerini söylemek mümkündür. Örneğin, 18-24 yaş aralığındaki bireylerin 55 yaş ve üstü bireylere oranla kadına şiddetle mücadeleyi başarılı görme olasılıkları \%137 daha yüksektir (exp ( $\beta$ ) $2,37-1=1,37)$. 
Tablo 12. Dizilerin Kadına Yönelik Şiddet Algısı Üzerindeki Etkileri

\begin{tabular}{|c|c|c|c|c|c|c|}
\hline Değişken & & $\beta$ & S.E. & Wald & $\mathrm{p}$ & $\operatorname{Exp}(\beta)$ \\
\hline \multirow{5}{*}{ Dizi İzleme Sıklığı } & Günde 1 saat & $-1,622$ & 239 & 46,013 & 000 & 0,19 \\
\hline & Günde 2 saat & $-1,041$ & 213 & 23,769 & 000 & 0,35 \\
\hline & Günde 3 saat & $-1,200$ & 176 & 46,348 & ,000 & 0,30 \\
\hline & Günde 4 saat &,- 363 & 215 & 2,869 & ,090 & 0,69 \\
\hline & Günde 5 saat ve üzeri (ref.) & 0 & . & . & . & \\
\hline \multirow{2}{*}{ Şiddet } & Evet & 364 & 134 & 7,418 & ,006 & 1,43 \\
\hline & Hayır (ref.) & 0 & 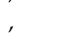 & , & , & \\
\hline \multirow{2}{*}{ Polisiye } & Evet & ,917 & 137 & 45,138 & ,000 & 2,5 \\
\hline & Hayır (ref.) & 0 & . & . & . & \\
\hline \multirow{2}{*}{ Hapishane } & Evet &, 546 & 214 & 6,479 & ,011 & 1,72 \\
\hline & Hayır (ref.) & 0 & . & . & . & \\
\hline \multirow{2}{*}{ Savaş } & Evet & 021 & 196 & ,011 & ,916 & 1,02 \\
\hline & Hayır (ref.) & 0 & . & . & . & \\
\hline \multirow{2}{*}{ Sağlık } & Evet & 031 & 138 & 051 &, 822 & 1,03 \\
\hline & Hayır (ref.) & 0 & . & . & . & \\
\hline \multirow{2}{*}{ Kadına Yönelik Şiddet } & Evet & 417 & 119 & 12,195 & ,000 & 1,517 \\
\hline & Hayır (ref.) & 0 & . & . & . & \\
\hline \multirow{2}{*}{ Cinsiyet } & Kadın &,- 656 & 128 & 26,332 & ,000 & 0,51 \\
\hline & Erkek (ref.) & 0 & . & . & . & \\
\hline \multirow{5}{*}{ Yaş } & $18-24$ &, 836 &, 224 & 13,965 & ,000 & 2,37 \\
\hline & $25-34$ & ,712 & 192 & 13,735 & 000 & 2,03 \\
\hline & $35-44$ & 805 & 193 & 17,409 & ,000 & 2,36 \\
\hline & $45-54$ & ,766 & 204 & 14,112 &, 000 & 2,15 \\
\hline & 55 ve üzeri (ref.) & 0 & . & . & . & \\
\hline \multirow{3}{*}{ Medeni Durum } & Evli &, 090 &, 382 &, 056 &, 813 & 1,09 \\
\hline & Bekar &,- 500 & 402 & 1,546 & 214 & 0,60 \\
\hline & Boşanmış/Dul (ref.) & 0 & . & . & . & \\
\hline \multirow{4}{*}{ Eğitim Durumu } & Diplomasız ve İlkokul Mezunu & 165 & ,175 &, 887 & ,346 & 1,179 \\
\hline & Ortaokul Mezunu & 242 & 194 & 1,556 & 212 & 1,273 \\
\hline & Lise Mezunu & 202 & 160 & 1,600 & 206 & 1,22 \\
\hline & $\begin{array}{l}\text { Üniversite ve Yüsek Okul Mezunu } \\
\text { (ref.) }\end{array}$ & 0 & . & . & . & \\
\hline
\end{tabular}

-2 Log Likelihood= 2496, $653 \chi^{2}=412,217 p<0,001$ Nagelkerte 0,324

\section{Tartışma}

Teknolojinin gelişimi ile birlikte kitle iletişim araçlarının yaygın kullanımının dünyanın her tarafında farklı kültürel özelliklere sahip toplumlarda şiddete eğilimi nasıl etkilediği, özellikle 20. yüzyılın başlarından itibaren çeşitli disiplinlerde araştırma konusu olmuştur. İletişim çalışmalarında baskın bir ekol olan anaakım (Anglo-Amerikan) araştırma geleneğini temel alan araştırmalar, medyada yer alan şiddet içerikleri ile donatılmış yayınların, toplumları ve bireyleri olumsuz etkilediğini ortaya koymaktadır (Dursun, 2010, s.20). Bu yaklaşım, medyada şiddet içeriğine sıklıkla yer verilmesinin, şiddetin sorunların çözümünde bir araç gibi benimsenmesi eğilimini artırdığı, şiddeti seyretmenin şiddet içeren davranışların oluşumunda ne- 
densel bir teşvik edici etken olduğu görüşünü benimsemektedir (Williams, 2003). Eleştirel medya araştırma geleneğinde ise şiddete dayalı davranışı toplumun desteklediği, bu davranışın topluma en kolay mesaj iletim aracı başta televizyon olmak üzere medya kullanımı temsil edilerek, sunulduğu görüşü savunulmaktadır (Williams, 2003, s.103). Kadın hareketlerinin gelişimi, özel olarak medyanın kadına yönelik şiddeti nasıl etkilediği sorusunu beraberinde getirirken, kadına yönelik şiddete karşı mücadelede başarı elde edilmesinde medyanın sunabileceği katkılara ilişkin tartışmaları da başlatmıştır. Bu bağlamda araştırmada, bir yandan toplumdaki kadına yönelik şiddetle mücadelenin nasıl algılandığı, diğer yandan da yerli dizilerin bireylerin kadına yönelik şiddetle mücadele algısını nasıl etkilediği araştırılmıştır.

Araştırmamıza katılan bireylerin yarısından fazlası (\%54) kadına yönelik şiddetle mücadeleyi yetersiz bulduğunu ifade etmiştir. Cinsiyet ve kadına şiddetle mücadele algısı arasındaki ilişkiyi inceleyen Mann-Whitney testi ve Sıralı Lojistik Regresyon sonuçları, kadınların erkeklere oranla kadına yönelik şiddetle mücadeleyi daha yetersiz buldukların göstermektedir. Dolaylı ve doğrudan mağduriyet, kadınların erkeklere oranla kadına yönelik şiddetle mücadeleyi yetersiz bulmalarının nedeni olabilir. Dolaylı mağduriyet, bir kişinin mağdur olmamasına rağmen çevresinden veya medya organlarından edindiği izlenimlerle bir suçtan etkilenmesidir (Aquino, Grover, Bradfield ve Allen, 1999). Yakın çevrede kadına yönelik şiddet olaylarına daha fazla tanık olunması veya çevrede kadına yönelik şiddetle ilgili konuların daha fazla konuşulması dolaylı mağduriyete yol açmış olabilir. Diğer yandan, kadınların kendilerinin de şiddete maruz kalmaları sebebiyle kadına yönelik şiddetle mücadelenin yetersiz olduğunu ifade etmiş olmaları muhtemeldir. Türkiye'de kadınların çoğunluğunun şiddeti meşru görmemeleri, şiddete karşı farkındalıklarının erkeklere nazaran daha yüksek düzeyde olmaları bu farkın oluşmasında etkili olabilir.

Kadına yönelik şiddetle mücadele algısında yaş farklılıkları incelendiğinde, ikili analiz sonuçlanı 18-24 yaş arası ve 55 yaş üstü bireylerin diğer yaş gruplarına oranla kadına yönelik şiddetle mücadeleyi daha yetersiz gördüklerini ortaya koymaktadır. Sıralı lojistik regresyon sonuçlarına göre ise, 18-24 yaş grubu gençler kadına yönelik şiddetle mücadeleyi diğer yaş gruplarına göre daha yetersiz bulmaktadır. Bu sonuç, kadına yönelik şiddetle mücadelenin toplumun her kesimine yaygın olarak anlatılması gerektiği- 
ni göstermektedir. Özellikle, diziler aracıllğıyla şiddetin bir sorun çözme yolu olmadığının gençlere aktarılabileceği söylenebilir.

Eğitim durumu sıralı lojistik regresyonda kadına yönelik şiddet algısı üzerinde istatistiksel olarak anlamlı bir sonuç üretmemiştir. Ancak, ikili ilişkileri inceleyen Mann-Whitney testi sonuçları diplomasız veya ilkokul mezunlarının ve üniversite ya da daha yüksek eğitime sahip olanların diğerlerine oranla kadına yönelik şiddetle mücadeleyi daha yetersiz bulduklarını ortaya koymaktadır. Kadına yönelik şiddet araştırmaları, eğitim seviyesi düşük kadınların ev ve aile ortamında şiddete daha fazla maruz kaldıklarını göstermektedir (Chowdhury vd., 2018; Peraica vd., 2021). Bu bağlamda, diplomasız ve ilkokul mezunu bireylerin kadına yönelik şiddetle mücadeleyi daha başarısız bulmaları, bu demografik grubun şiddetle daha çok karşı karşıya kalmalarının bir yansıması olabileceği gibi, eğitim seviyesi yükseldikçe kadınların şiddetle karşılaşmaları halinde toplumsal statülerinin sarsılabileceği kaygısıyla bunu ifade etmekten kaçınmalarından da kaynaklanabilir. Bununla beraber, üniversite ve daha yüksek eğitime sahip bireylerin durumsal farkındalıklarının yüksek olması, kadına yönelik şiddetle mücadeleyi yetersiz bulmalarının nedeni olabilir.

İkinci araştırma sorumuz, yerli dizi izleme alışkanlıklarının kadına yönelik şiddetle mücadele algısı üzerindeki etkilerini ölçmeye yönelikti. Öncelikle yerli dizilerde tasvir edilen kadına yönelik şiddet unsurlarının bireylerce nasıl algılandığını ölçmeye yönelik 6 adet soru sorulmuştur. Bu sorulara verilen yanıtlar, kadına yönelik şiddet temalı dizilerin kadına yönelik şiddet konusunda, toplumda farkındalık yaratmak, toplumu kadına yönelik şiddete karşı birleşme konusunda teşvik etmek, şiddet gören kadınların psikolojik şartlarını ortaya koymak ve kadına yönelik şiddetin suç olduğunu göstermek gibi rolleri olduğunu sergilemektedir. Bu kapsamda, kadına yönelik şiddet temalı dizilerin, kadına yönelik şiddetin boyutlarının ve olumsuz etkilerinin toplumca daha iyi anlaşılmasına katkıda bulunduğunu söylemek mümkündür.

Dizi izleme sıklığı, farklı temalardaki dizilerin kadına yönelik şiddetle mücadele algısı üzerindeki etkilerini araştırdığımız Sıralı Lojistik Regresyon analizi sonuçlarına göre, dizi izleme sıklığı arttıkça bireylerin kadına yönelik şiddetle mücadelenin yeterliliği hakkında olumlu tutum geliştirme olasıllğ da artmaktadır. Bu sonuç önceki paragrafta verilen betimsel istatistik verilerini destekler niteliktedir. Yerli dizilerin etkilerinin temaları kapsamında 
incelendiğinde, şiddet içerikli, polisiye, hapishane ve kadına yönelik şiddet temalı dizileri izleyenler, izlemeyenlere oranla olumlu tutum geliştirme olasılıkları daha yüksektir. Hapishane ve savaş temalı dizileri sıklıkla izlemenin kadına yönelik şiddet algısı üzerinde istatistiksel olarak anlamlı bir etkisi görülmemiştir. Bu dizilerde kadına yönelik şiddetin fazla yer bulamaması, istatistiksel olarak anlamlı ilişkinin yokluğunun bir nedeni olabilir.

Gerbner (1991, s. 11), medyanın gücünü, bir sanayi toplumunda imgesel düşüncelerin ve bilincin ekilmesi (cultivation) işlevini üstlenebilme kabiliyeti ile ilişkilendirmektedir. Televizyonda yayınlanan programlar nasıl şiddetin yayılmasında ve meşrulaştırılmasında etkili oluyorsa, bu durum televizyon yayınlarının kadına yönelik şiddetle mücadele konusunda başarıya ulaşmanın da anahtarı olabilir. Araştırma sonuçlarımıza göre Türkiye'de bireylerin \%84,6'sı günde 3 saatten fazla süreyle televizyon yayını izlerken, $\% 74,3$ 'ü de günde 3 saatten fazla süreyle yerli dizi izlemektedir. Türkiye'de bireylerin televizyon yayını izleme süreleri dikkate alındığında yerli dizilerin bireylerin kadına şiddetle mücadele programları çerçevesinde dizayn edilerek, konu hakkındaki durumsal farkındalığın artırılmasına ve kadına yönelik şiddetle mücadele yöntemleri hakkında bilgi sahibi olmalarına katkıda bulunulabilir.

\section{Sonuç}

Kadına yönelik şiddet suçun karanlık alanında kalan suç türlerinden birisidir. Fiziksel, ekonomik, psikolojik veya sözlü şiddete maruz kalan kadınlar zaman zaman bu sorunu kolluk birimlerine veya çevrelerine anlatmak yerine problemi kabullenmek zorunda kalabilmektedir. Şiddetin çoğu zaman sadece fiziksel şiddet olarak algılanması da kadına yönelik şiddetin farklı boyutlarının varlığını sürdürmesine neden olabilmektedir.

İnternet tabanlı teknolojilerin sunduğu eğlence imkânlarının hayatımızda yaygınlaşması ile beraber televizyon artık tek eğlence ve vakit geçirme aracı olmasa da, televizyon yayınları hala yoğun olarak izlenmektedir. Son yıllarda kadına yönelik şiddet araştırmalarında bir artış olmakla beraber yerli dizilerin kadına yönelik şiddetle mücadele algısı üzerindeki etkileri henüz kapsamlı olarak araştırılmamıştır. Literatürdeki bu açığa bir katkı sağlamayı amaçlayan çalışmamızda alınan izinle İçişleri Bakanlığı İç Güven- 
lik Stratejileri Dairesi Başkanlığınca yürütülen bir proje kapsamında toplanan veriler analize tabi tutulmuştur.

Araştırmamızın literatüre en önemli katkısı, yerli dizilerin kadına yönelik şiddetle mücadele algısına olumlu katkıları olabileceğini ortaya koymasıdır. Türkiye'de son yıllarda kadına yönelik şiddetle ilgili olarak çeşitli inisiyatifler geliştirilmiştir. Özellikle ŞÖNIM ve KADES uygulamaları ile kadına yönelik şiddetin önlenmesi ve toplumsal farkındalığın arttırılması konularında önemli mesafeler kaydedilmiştir. Politika üreticiler, yerli dizilerde kadına yönelik şiddet temasını daha fazla işlenmesini sağlayarak, özellikle kadınların farklı şiddet türleri (ekonomik, cinsel ve psikolojik) hakkında bilinçlenme ve bu şiddet türlerine karşı koyma stratejileri geliştirmelerine katkıda bulunabilir. Ayrıca, erkek izleyicisi yoğun olan dizilerde kadına yönelik şiddetin insan hakkı ihlali olduğu, şiddetin her türünün meşru olmadığı gibi mesajların verilmesi ile erkeklerin kadına yönelik şiddetle mücadele konusunda duyarlılıklarının ve farkındalıklarının artırılmasına olumlu etkide bulunabilir.

Araştırmamızın bir başka önemli sonucu da Türkiye'de kadına şiddetle mücadele algısının gençler ve yaşlılar arasında diğer demografik gruplara göre daha az olduğunu ortaya koymasıdır. Kamu spotlarının bu yaş gruplarının dikkatini ve ilgisini çekecek şekilde hazırlanmasıyla genç ve yaşlı nüfusun bu konuda daha fazla bilgilendirilmesi sağlanabilir. Şiddet döngüsünün kırılmasında, şiddet içermeyen bir ortamda toplumsallaşma büyük önem taşımaktadır. Böyle bir ortamın sağlanmasında, eğitim ve diğer kitle iletişim araçlarının yanı sıra dizilerden de faydalanılabileceği görülmektedir.

Son yıllarda yapılan çalışmalar ile kadına yönelik şiddetle mücadele önemli bir devlet politikası haline gelmiştir. Araştırmamızın sonuçlarının kadına yönelik şiddetle ilgili olarak yeni kamu politikalarının geliştirmesine katkı sağlayacağını ümid ediyoruz. 
EXTENDED ABSTRACT

\title{
The Impact of TV Series on the Perception of Combating Violence Against Women in Turkey
}

\author{
Can Ozan Tuncer- Serpil Seda Şimşek- Naci Akdemir \\ Van Yüzüncü Yıl University-Gendarmerie and Coast Guard Academy-Gendarmerie and Coast \\ Guard Academy
}

Violence against women is defined by United Nations as "any act of gender-based violence that results in, or is likely to result in physical, sexual or psychological harm or suffering to women, including threats of such acts, coercion or arbitrary deprivation of liberty, whether occurring in public or private life." World Health Organization considers violence against women as human rights violation and a significant health issue. It is estimated that one out of three women faces intimate partner and non-partner violence in their lives across the globe. Turkish women and girls are also unfortunately subject to violence. According to a research conducted by the General Directorate on the Status of Women (KSGM) (2009), 44\% of married women in Turkey stated that they had been exposed to at least one act of emotional abuse at any point in their lives. In addition, 37\% of women indicated that their husbands abused them, and one-fifth of married women acknowledged that they were humiliated by their husbands at least once in their lifetime. These figures and media news caused a moral panic in Turkey, which in turn rendered combating violence against women as Tier One policy.

The Turkish Government implemented several policies such as Centers for Prevention and Monitoring Violence (ŞÖNIM) and Women Immediate Support (KADES) to prevent increasing violent offences. Although these measures, to some extent, were successful in reducing the harm received, the public perception of combatting violence against women is not clear. This research address this gap in the literature. Moreover, the severity of the problem attracted considerable scholars interest in the issue. Causes of violence against women, adverse effects of violence against women and characteristics of the perpetrators were the most frequently researched subjects. Although networked internet technologies 
have become a significant source of entertainment, television is still considered a powerful medium of communication and entertainment. Research examining the impact of TV series suggests that TV series may have a considerable impact on individuals' perceptions. Yet, the effect of TV series on the perception of violence against women is understudied. The first aim of our empirical study was to understand how combating violence against women is perceived in Turkey. The second was to examine the effects of TV series on the perception of tackling violence against women. To these ends, the survey data collected by the Department of Internal Security Strategies of the Ministry of Interior as a part of the research were subjected to quantitative analysis (Mann-Whitney, Kruskal Wallis and Ordered Logistic Regression analyses).

Frequency of watching TV series, the type of TV series watched frequently (i.e. violence, drama or crime) and demographic characteristics included in the model as dependent variables. Descriptive statistics illustrated that $54 \%$ of participants found combating violence against women inadequate. Moreover, bivariate analysis results indicate gender and age differences in the perception of tackling violence against women. The results suggest that women, young people (18-24 years old) and the elderly (55 years old and above) find the combating violence against women inadequate compared to the other demographic groups. Multivariate analysis demonstrated that the frequency of watching TV series and TV series themed with violence, crime, prison and violence against women were the predictors of the perception of combating violence against women. The ordered logistic regression model suggested that individuals who watched TV series more frequently found tackling violence against women adequate compared to those who watch TV series less regularly.

The media is one of the channels where the perspectives on violence against women and forms of violence against women are reflected most strikingly. With this regard, media representation of violence against women becomes essential. Our research illustrated that TV series positively impacted the perception of violence against women and that domestic TV series may help raise situational awareness about violence against women.

Violence against women mostly remains in the dark figure of crime. The dark figure of crime is the term that refers to the crimes that are unre- 
ported or unrecorded. Besides socio-economic factors and fear of secondary victimization, lack of knowledge about coping with intimate partner violence leads to non-reporting. Centres for Prevention and Monitoring Violence (ŞÖNIM) and Women Immediate Support (KADES) were established to combat violence against women. However, their visibility in society may be limited. Our research suggested that participants considered TV series informative about violence against women. With this regard, policymakers may consider utilizing the effects of TV series on raising awareness in society about the types of violence against women and the adverse psycho-social impacts of violence on women while developing strategies to combat violence against women.

\section{Kaynakça/References}

Aile, Çalışma ve Sosyal Hizmetler Bakanlığı. (2019). Kadına yönelik şiddetle mücadele koordinasyon planı 2020-2021. 08 Nisan 2021 tarihinde https://www.ailevecalisma.gov.tr/media/33061/koordinasyon-plani-v13-1.pdf adresinden erişildi.

Aile ve Sosyal Politikalar Bakanlı̆̆ı Kadın Statüsü Genel Müdürlüğü. (2014). Türkiye'de kadına yönelik aile içi şiddet araştırması. Hacettepe Üniversitesi Nüfus Etütleri Enstitüsü. 01 Nisan 2021 tarihinde http://www.hips.hacettepe.edu.tr/TKAA2014 Ozet Rapor.pdf adresinden erişildi.

Akkuş, S. ve Yıldırım, Ş. (2018). Erkeklerin kadına yönelik fiziksel şiddet uygulamasına etki eden faktörlerin incelenmesi. Gaziantep University Journal of Social Sciences, 17(4), 1368-1388.

Altınay, A. G. ve Arat, Y. (2007). Türkiye'de kadına yönelik şiddet. İstanbul: Punto.

Altıparmak, İ. B. (2019). Kadına yönelik aile içi şiddetin boyutları: Ankara örneği. Celal Bayar Üniversitesi Sosyal Bilimler Dergisi, 17(01), 55-76.

Aquino, K., Grover, S. L., Bradfield, M. and Allen, D. G. (1999). The effects of negative affectivity, hierarchical status, and self-determination on workplace victimization. Academy of management journal, 42(3), 260-272.

Bryman, A. (2008). Social research methods. Oxford: Oxford University Press.

Chowdhury, S. R., Bohara, A. K., and Horn, B. P. (2018). Balance of power, domestic violence, and health injuries: Evidence from demographic and health survey of Nepal. World development, 102, 18-29. 
Creswell, J. W. 2009, Research Design: Qualitative, Quantitative, and Mixed Methods Approaches. Thousand Oaks, CA London: Sage Publications.

Demirdirek, H. ve Şener, Ü. (2014). 81 il için toplumsal cinsiyet eşitliği karnesi. Türkiye Ekonomi Politikaları Araştırma Vakfı. Ankara: Mattek Matbaacılık.

Doğrucan, A. ve Yıldırım, Z. (2020). Kadına yönelik aile içi şiddet üzerine bir inceleme. Hacettepe Üniversitesi Sosyal Bilimler Dergisi, 2(2), 122-138.

Dökmen, Z. (2009). Toplumsal cinsiyet sosyal psikolojik açıklamalar. İstanbul: Remzi Kitabevi.

Dursun, Ç. (2010). Kadına yönelik şiddet karşısında haber etiği. Fe Dergisi 2, 1929.

Erdem, M. N. (2020). Medya içeriğinde şiddetin sunumu üzerine argümantatif bir çalışma. Manas Sosyal Araştırmalar Dergisi, 9(2), 1198-1217.

Erden, G. ve Akdur, S. (2018). Türkiye'de kadına yönelik aile içi şiddet ve kadın cinayetleri. Klinik Psikoloji Dergisi, 2(3), 128-139.

Ergönen, A. T., Özdemir, M. H., Can, İ. Ö., Sönmez, E., Salaçin, S., Berberoglu, E. ve Demir, N. (2009). Domestic violence on pregnant women in Turkey. Journal of Forensic and Legal Medicine, 16(3), 125-129.

Gerbner, G. (1991). Journey into Media Violence: A Happy Land of Power, Politics, and Publicity and Maybe Profits. Mimeograph.

Goodwin, J. 2012. Sage secondary data analysis. UK: Sage.

Güleç, H., Topaloğlu, M, Ünsal, D. ve Altıntaş, M. (2012). Bir kısır döngü olarak şiddet. Psikiyatride Güncel Yaklaşımlar, 4(1), 112-137.

Harrell, F. E. (2015). Ordinal logistic regression. Harrell, F. E. Regression modeling strategies içinde (s.311-325). Springer.

Hürriyet Gazetesi (19 Nisan 2021). Dayakçı eşe 700 km'den müdahale. 10 Temmuz 2021 tarihinde https://www.hurriyet.com.tr/gundem/dayakciese-700-kmden-mudahale-41791615 adresinden erişildi.

İçişleri Bakanlığı. (9 Nisan 2021). İçişleri Bakanı Süleyman Soylu: 2020 yılına oranla kadın cinayetlerinde yüzde 21 azalma sağlandı. 10 Nisan 2021 tarihinde https://www.icisleri.gov.tr/bakanimiz-sn-suleyman-soylu-2020yilina-oranla-kadin-cinayetlerinde-yuzde-21-azalma-saglandi adresinden erişildi.

İçişleri Bakanlığı. (15 Nisan 2021). Kasten öldürme olaylarında son 15 Yılda \%31,5'lik düşüş sağlandı 18 Nisan 2021 tarihinde https://wwww.icisleri.gov.tr/kasten-oldurme-olaylarinda-son-15-yilda-315likdusus-saglandi adresinden erişildi. 
İçişleri Bakanlığı İç Güvenlik Stratejileri Dairesi Başkanlığı. (2020). Aile içi şiddet ve kadın cinayetlerinin önlenmesinde kolluğun önemi ve rolü. Ankara: İçişleri Bakanlığı.

Kadına Yönelik Şiddetle Mücadele IV. Ulusal Eylem Planı 2021-2025. (1 Temmuz 2021). 5 Temmuz 2021 tarihinde https://www.aile.gov.tr/media/82082/kadina-yonelik-siddetle-mucadele-ivulusal-eylem-plani-2021-2025.pdf adresinden erişildi.

Kadının Statüsü Genel Müdürlüğü (KSGM). (2009). Türkiye'de kadına yönelik aile içi şiddet. (Yazarlar: S. Üner, F. Kardam, H. Jansen, S. Tezcan, B. Ergöçmen, S. Türkyılmaz, İ. Yüksel, İ. Koç, E. Yiğit, Y. Coşkun). Ankara: Elma Teknik Basım Matbaacılı. 18 Temmuz 2021 tarihinde http://www.hips.hacettepe.edu.tr/TKAA2008-AnaRapor.pdf adresinden erişildi.

Liu, X., and Koirala, H. (2012). Ordinal regression analysis: Using generalized ordinal logistic regression models to estimate educational data. Journal of modern Applied Statistical methods, 11(1), 21.

Manchikanti Gómez, A. (2011). Testing the cycle of violence hypothesis: Child abuse and adolescent dating violence as predictors of intimate partner violence in young adulthood. Youth \& Society, 43(1), 171-192.

McKnight, P. E. and Najab, J. (2010). Mann-Whitney U Test. The Corsini encyclopedia of psychology, 4, 1-1.

Nisan, F. ve Işık, T. (2020). Kadına Şiddetin Haberlerde Sunumu: Emine Bulut Örneği. Uluslararası Kültürel ve Sosyal Araştırmalar Dergisi (UKSAD), 6(1), 104-123.

Ökten, Ş. (2009). Toplumsal cinsiyet ve iktidar: Güneydoğu Anadolu Bölgesi'nin toplumsal cinsiyet düzeni. Uluslararası Sosyal Araştırmalar Dergisi, 2(8), 302-312.

Özcan, A. (2012). Toplumsal cinsiyet eğitiminin üniversite öğrencilerinin toplumsal cinsiyet rol tutumlarına etkisi. Yayımlanmamış doktora tezi. Erciyes Üniversitesi, Kayseri.

Özgentürk, İ., Karğın, V. ve Baltacı, H. (2012). Aile içi şiddet ve şiddetin nesilden nesile iletilmesi. Polis Bilimleri Dergisi, 14(4), 55-77.

Peraica, T., Petrović, Z. K., Barić, Ž., Galić, R. and Kozarić-Kovačić, D. (2021). Gender differences among domestic violence help-seekers: Sociodemographic characteristics, types and duration of violence, perpetrators, and interventions. Journal of Family Violence, 36(4), 429-442. 
Resmi Gazete. (20 Mart 2021). (Sayı: 28239). Ailenin korunması ve kadına karşı şiddetin önlenmesine dair kanun. 28 Mart 2021 tarihinde http://www.resmigazete.gov.trleskiler/2012/03/20120320-16.htm adresinden erişildi.

Sancar, S. (2013). Erkeklik: Imkansiz iktidar. (3 bs.). İstanbul: Metis.

Şener, G., Çavuşoğlu, Ç. ve Irklı, H. İ. (2016). Medya ve toplumsal cinsiyet. F. Saygilıgil (hzl.). Toplumsal Cinsiyet Tartışmaları içinde (s.166-183). Ankara: Dipnot.

Taştan, C. ve Küçüker, Y. A. (2019). Dünyada ve Türkiye'de kadın cinayetleri 20162017-2018 verileri ve analizleri. Ankara: Polis Akademisi Yayınları. 03 Nisan 2021 tarihinde https://www.pa.edu.tr/Upload/editor/files/Kadin Cinayetleri Rapor.pdf adresinden erişildi.

T. C. Aile ve Sosyal Politikalar Bakanlığı, Hacettepe Üniversitesi Nüfus Etütleri Enstitüsü. (2015). Türkiye'de kadına yönelik aile içi şiddet araştırması. Ankara: Elma Teknik Basın Matbaacilı. 18 Temmuz 2021 tarihinde http://www.hips.hacettepe.edu.tr/KKSA-TRAnaRaporKitap26Mart.pdf adresinden erişildi.

T.C. Aile ve Sosyal Politikalar Bakanlığı Kadının Statüsü Genel Müdürlüğü, Hacettepe Üniversitesi Nüfus Etütleri Enstitüsü. (2014). Türkiye'de kadına yönelik aile içi şiddet araştırması 2014. 18 Temmuz 2021 tarihinde http://www.hips.hacettepe.edu.tr/siddet2014/ adresinden erişildi.

Tozlu, N. ve Solak, A. (2008). Medya ve şiddet. N. Tozlu, İ. Doğan, D. Ekiz, T. K. Wonder, E. Sarı (Haz.), Küresel Süreçte Medya ve Şiddet içinde (s.50 138). İstanbul: HEGEM Yayınları.

TRT Haber. (2 Ocak 2021). Tedbirler sonuç verdi, 2020'de kadın cinayetleri yüzde 21 azaldı 03 Nisan 2021 tarihinde https://www.trthaber.com/haber/gundem/tedbirler-sonuc-verdi-2020de-kadincinayetleri-yuzde-21-azaldi-543357.html adresinden erişildi.

Türkiye İstatistik Kurumu (TÜIK). (2008). Kadına yönelik aile içi şiddet istatis$\begin{array}{lllll}\text { tikleri. } & 03 & \text { Nisan } & 2021 & \text { tarihinde }\end{array}$ https://biruni.tuik.gov.tr/kadinasiddetdagitim/kadin.zul adresinden erişildi.

Türkiye' de Şiddeti Önleme ve İzleme Merkezleri. (2021). 08 Nisan 2021 tarihinde https://www.ailevecalisma.gov.tr/tr-tr/iletisim/bakanlik-iletisimbilgileri/bagli-ilgili-ve-ozel-kuruluslar1/sonim/ adresinden erişildi.

United Nations Office on Drugs and Crime (UNODC). (2019). Global study on homicide. Booklet 5: Gender-related killing of women and girls. 10 Mays 2021 
tarihinde

https://www.unodc.org/documents/data-andanalysis/gsh/Booklet_5.pdf adresinden erişildi.

Williams, R. (2003). Televizyon, teknoloji ve kültürel biçim. (A. U. Türkbağ, Çev.). Ankara: Dost.

World Health Organization (WHO). (2013). Global and regional estimates of violence against women: prevalence and health effects of intimate partner violence and non-partner sexual violence. 01 Nisan 2021 tarihinde http://apps.who.int/iris/bitstream/10665/85239/1/9789241564625 eng.pdf adresinden erişildi.

World Health Organization (WHO). (2021). Violence against women data. 01 Nisan 2021 tarihinde https://www.who.int/data/sexual-and-reproductivehealth-and-rights/violence-against-women-data adresinden erişildi.

Yazıcı, F. ve Şahbaz, Y. D. (2020). Toplumsal cinsiyet bağlamında kadına yönelik şiddet ve Türkiye'de yazılı basına yansıması. Intermedia International eJournal, 7(12), $129-148$.

Yıldırım, A. (1998). Siradan Şiddet - kadına ve çocuğa yönelik şiddetin toplumsal kaynakları. İstanbul: Boyut Kitapları.

\section{Kaynakça Bilgisi/Citation Information}

Tuncer, C. O., Şimşek, S. S. ve Akdemir, N. (2021). Türkiye'de yerli dizilerin kadına yönelik şiddetle mücadele algısı üzerine etkileri. OPUS- Uluslararası Toplum Araştırmaları Dergisi, 18(41), 33623395. DOI:10.26466//opus.975120. 